\title{
Comparison between different sources of minerals in horses with nutritional secondary hyperparathyroidism
}

\author{
[Comparação entre diferentes fontes de minerais em cavalos com hiperparatireoidismo \\ secundário nutricional] \\ A.A.O. Gobesso ${ }^{1}$, H. Wajnsztejn ${ }^{2}$, R.M. Ribeiro ${ }^{3}$, F.L. Bastos ${ }^{4}$, \\ M. Etchichury ${ }^{4}$, A.M.C. Araújo Júnior ${ }^{4}$ \\ ${ }^{1}$ Faculdade de Medicina Veterinária e Zootecnia - Pirassununga, SP \\ ${ }^{2}$ Medicina Veterinária - Universidade de Sorocaba - Sorocaba, SP \\ ${ }^{3}$ Centro Universitário de Mineiros - Mineiros, GO \\ ${ }^{4}$ Aluno de pós-graduação - Faculdade de Medicina Veterinária e Zootecnia - Pirassununga, SP
}

\begin{abstract}
Minerals perform several functions in the body, such as coagulation actions, muscle contraction, enzymatic and hormonal production, among others. This study aims to evaluate the effect of a 150 days chelated and not chelated mineral supplementation with and without potassium oxalate on serological parameters and bone mineral density of horses. Twenty-four crossbred yearlings ( 12 females and 12 males) with an average age of $21 \pm 3$ months and body weight of $330.8 \pm 37.9 \mathrm{~kg}$ were divided into four groups containing six equines in each (three females and three males) in a completely randomized design with repeated measurements in a $2 \times 2$ factorial arrangement. Treatments were: 1 - chelated minerals compound; 2 - chelated minerals compound and potassium oxalate; 3 - not chelated minerals compound; and 4 - not chelated minerals compound and potassium oxalate. Clinical signs of nutritional secondary hyperparathyroidism (NSH) were observed only in treatment 4 . Results showed no treatment effect in bone biopsy for calcium, phosphorus and bone density. There were significant reductions of parathyroid hormone (PTH) means concentrations in treatments 2 and 4 during supplementation. Animals supplemented with chelated minerals compounds avoided mineral imbalances and NSH even when in dietary potassium oxalate challenged.
\end{abstract}

Keywords: blood analysis, calcium, chelates, foals, phosphorus

\section{RESUMO}

Os minerais desempenham diversas funções no organismo, como ações de coagulação, contração muscular, produção enzimática e hormonal, entre outras. O objetivo deste estudo foi avaliar o efeito da suplementação de minerais quelatados e não quelatados, por 150 dias, com e sem oxalato de potássio, sobre parâmetros sorológicos e densidade mineral óssea em equinos. Vinte e quatro filhotes mestiços (12 fêmeas e 12 machos), com idade média de $21 \pm 3$ meses e peso corporal de 330,8 $\pm 37,9 \mathrm{~kg}$, foram divididos em quatro grupos contendo seis equinos cada (três fêmeas e três machos), em delineamento inteiramente ao acaso, com repetição medida em arranjo fatorial $2 \times 2$. Os tratamentos foram: 1 - composto mineral quelatado; 2 - composto mineral quelatado e oxalato de potássio; 3 - composto mineral não quelatado; $e$ 4 - composto mineral não quelatado e oxalato de potássio. Os sinais clínicos do hiperparatireoidismo secundário nutricional (NSH) foram observados apenas no tratamento 4. Os resultados não mostraram efeito de tratamento na biópsia óssea para cálcio, fósforo e densidade óssea. Houve redução significativa do hormônio da paratireoide (PTH) em concentrações médias nos tratamentos 2 e 4 durante a suplementação. Os animais suplementados com compostos minerais quelatados evitaram desequilíbrios minerais e NSH, mesmo quando desafiados no oxalato de potássio na dieta.

Palavras-chave: análise de sangue, cálcio, quelatos, potros, fósforo

Recebido em 23 de julho de 2020

Aceito em 22 de setembro de 2020

E-mail: gobesso.fmvz@usp.br 


\section{INTRODUCTION}

Deficiency of mineral compounds relative to the needs of animals often present in fodders as well as low assimilability of compounds necessitates supplementation of feed rations (Stanek et al., 2016). In central Brazil, especially in savannah areas, Brachiaria humidicola constitutes the only practical option to pasture work horses and with a simple handling, its seeds and seedlings propagates even in high acidity soil (Nunes et al., 1990). Similar to other grasses, such as Setaria anceps, Cenchrus ciliaris, Panicum maximum cultivar Aruana var. trichoglume, Pennisetum clandistinum, the Brachiaria spp. pasture contains a compound called oxalate that binds to divalent cations (such as calcium and magnesium), decreasing its' availability and use (Miyasaki et al., 2003).

According to Nutrient Requirements Council (Nutrient..., 2007), many other grasses contains excessive potassium oxalate amounts, contributing to the development of fibrous osteodystrophy - nutritional secondary hyperparathyroidism (NSH). Added to that fact, most mineral supplements for horses were composed by inorganic forms of elements, which were characterized by low assimilability (Stanek et al., 2016) and the use of unbalanced diets, with below recommended calcium levels, can also cause other diseases (Ospina et al., 2014).

Parathyroid hormone (PTH) with calcitonin and calcitriol (active vitamin D) are responsible for calcium concentration regulation in extracellular fluids. The main function of PTH is to maintain plasma calcium (Ca) concentrations (Barber, 2004). Increased PTH in response to decreased plasma $\mathrm{Ca}$ may results in bone resorption and changes in mineral homeostasis, causing parathyroid gland dysfunction, which can induce bone tissue loss and subsequent replacement of bone tissue by fibrous connective tissue (PuoliFilho et al., 1999).

This impact on horses' metabolism has been reported for years by some researchers. Swartzmann et al. (1978) noticed reduction of calcium absorption around $66 \mathrm{gkg}^{-1}$ with the inclusion of $10 \mathrm{gkg}^{-1}$ oxalic acid in equine diets. Blaney et al. (1981) observed negative balance for calcium in horses fed various tropical grass hays containing more than $0.5 \%$ total oxalate. On a weight-to-weight basis, when calcium:oxalate ratio was less than 0.5 , it was concluded that horses could be at risk due to nutritional secondary hyperparathyroidism. In a recent study with ponies, it was confirmed that soursop grazing ends up negatively affecting horses, with onset of acute hypocalcemia or secondary nutritional hyperparathyroidism, suggesting that oxalate toxicity is the cause of clinical signs observed in the affected animals (Herbert and Dittmer, 2017).

Many performance animal diets are supplemented with grain concentrates which provide minerals in order to fill the missing gaps in their diet (Herrick, 1993; Yenice et al., 2015). However, inorganic minerals need to become biologically active forms for their complete absorption (Spears, 1996). After binding to amino acids, proteins or carbohydrates (Mellor, 1964), metal ions become chelated with covalent bonds that make them more stable and easily absorbed than inorganic forms in the intestinal lumen (Lesson and Summers, 1997; Silva and Pascoal, 2014), increasing its bioavailability. According Forbes and Erdman (1983); Fairweather-Tait and Hurrell (1996); Kienzle and Zorn (2006), bioavailability refers to the efficiency in which a nutrient can be absorbed, enter circulation, and subsequently be used and/or stored by the body).

Oxide-linked minerals are considered less bioavailable than organic sulphates and chelates, but studies were inconclusive in indicating whether organic sulphates or chelates offer availability and use advantages (Ammerman et al., 1995). Some studies with equids have found no difference in utilization of minerals from chelated and not chelated sources (Siciliano et al., 2001; Baker et al., 2005). Other studies found an advantage for chelated mineral supplementation in some classes of horses, but not in all of the measures of interest (Ott and Asquith, 1994; Ott and Johnson, 2001). Also, mineral balance studies have yielded mixed results (Miller et al., 2003; Baker et al., 2005; Wagner et al., 2005). Therefore, the present study aimed to measure serological parameters and bone mineral density to quantify mineral body contents and evaluate the effect of potassium oxalate in yearlings' supplementation, besides determining if chelated minerals compounds - in comparison with not chelated - were able to prevent the development of pathology. 


\section{MATERIALS AND METHODS}

The procedures performed in this study were approved by the ethical committee on animal experimentation of the School of Veterinary Medicine and Animal Science, University of São Paulo (FMVZ/USP) and registered under the protocol number 1365/2008. The experiment was conducted in the city of Pirassununga, São Paulo State, Brazil. Twenty-four crossbred horses (12 females and 12 males) with an average age $21 \pm 3$ months and weight $330.8 \pm 37.9 \mathrm{~kg}$ were used. The animals were kept on intensive management in the field and housed in dry lot paddocks for data collection and provision of the experimental diet

The sampling phase lasted 150 days. A randomized design with repeated measures in a $2 \times 2$ factorial arrangement were used. There were 6 equines per treatment group ( 3 males and 3 females), resulting in four treatment groups: 1- chelated minerals compound; 2 - chelated minerals compound and potassium oxalate; 3 - not chelated minerals compound; and 4- not chelated minerals compound and potassium oxalate. Twice a day, each animal received concentrated food in individual feeders. The contents of potassium oxalate capsules $\left(25 \mathrm{gkg}^{-1}\right)$ were individually added to the animals' diet (only in groups 2 and 4) at this time. After total consumption, they were released into dry lot paddocks. Every fifteen days, all animals were weighed on a mechanical scale, aiming to weight assessment over time and individual potassium oxalate requirements adjust. Diet consisted of $500 \mathrm{gkg}^{-1}$ experimental concentrate with chelated or not chelated mineral, according to the treatment group (Table 1), and $500 \mathrm{gkg}^{-1}$ of Tifton-85 hay (Cynodon dactylon (L.) Pers. cv. Tifton-85) at $20 \mathrm{gkg}^{-1}$ of body weight twice a day. The forage was kept on mangers, and animals had free access to water.

Table 1. Mineral composition $\left(\mathrm{gkg}^{-1}\right)$ of diets concentrated with chelated and not chelated form

\begin{tabular}{lcc}
\multicolumn{1}{c}{ Ingredients } & Chelated & Not chelated \\
\hline Carbonate Calcium & - & 8.83 \\
Fosfate Bicalcium & 9.74 & 38.46 \\
Sodium chloride & 36.524 & 38.462 \\
Chelated Copper & 1.0 & - \\
Sulphate Copper & - & 0.286 \\
Chelated Zinc & 3.7 & - \\
Sulfate Zinc & - & 1.0 \\
Chelated Cobalt & 0.01 & - \\
Cobalt sulfate & - & 0.014 \\
Chelated manganese & 2.0 & - \\
Sulfate Manganese & - & 0.69 \\
Iodate Calcium & 0.015 & 0.015 \\
Chelated selenium & 0.011 & - \\
Sodium selenite & - & 0.047 \\
Chelated sulfur & - & 0.23 \\
Sulfur & 5.0 & - \\
Chelated iron & 2.0 & - \\
Chelated calcium & 40.0 & - \\
q.s. & - & 11.966 \\
\hline
\end{tabular}

Blood samples for biochemical analysis (parathyroid hormone and calcitonin) were collected monthly by jugular vein puncture in vacuum tubes. All samples were centrifuged, and the resulting supernatants were stored in microtubes (Eppendorf ${ }^{\odot}$ ) at $-20{ }^{\circ} \mathrm{C}$ until further chemiluminescence analysis (DPC ${ }^{\odot}$ kits). All animals were daily observed. Claudication tests (step and trot) and clinical examination looking for changes in bone face were performed weekly.
Radiological examinations were performed monthly on the third right metacarpal bone, and the optical densitometry was analyzed from radiographic images. A portable $\mathrm{X}$-ray machine (Min-X-Ray model HF8015+dlp ultra-light, Northbrook, Illinois/USA) were used, and an aluminum step wedge as the standard to determine the bone mineral density (BMD) were performed according to the methodology proposed by Vulcano et al. (2006). Bone metaphysis were 
analyzed as described by Santos et al. (2008). The radiographic images were digitalized on a flatbed scanner (Scanjet 6300C model, Hewlett Packard) and converted to grayscale tones using the HP Precision Scan Program ${ }^{\odot}$. The final images were processed and analyzed with specific software (ImageLab ${ }^{\odot}$ - Softium).

For bone calcium (Ca) and phosphorus (P) measurements, samples from iliac tuberosity were collected on Day 0, and then every 75 days (Day 75 and 150) using a low speed drill (Skil@ 9.6 V) and $8 \mathrm{~mm}$ punch, after sedation (detomidine hydrochloride), shaving, asepsis (chlorhexidine) and local anesthesia (lidocaine $20 \mathrm{gkg}^{-1}$ without vasoconstrictor). The region was exposed after a $1 \mathrm{~cm}$ skin incision and the bone fragments were removed and kept in $70 \%$ alcoholic solution until further analysis. The samples were dried, degreased and subsequently placed in a $600{ }^{\circ} \mathrm{C}$ muffle furnace for six hours. The ash was dissolved with a $500 \mathrm{gkg}^{-1}$ hydrochloric acid hot solution. Calcium was determined with atomic absorption spectroscopy, and phosphorus was assessed using a simplified colorimetric method, as described by Brasil (1988).

The results were submitted to analysis of variance (ANOVA) and checked for data normality by the Shapiro-Wilk test and the homogeneity of variances by the Levene test. The MIXED procedure of SAS statistical package (Statistical Analysis System, version 9.1.3.) was applied and the means were compared by Tukey test, with significance level of 0.05 .

\section{RESULTS}

All animals completed the experiment successfully without any complications, as lameness and/or spontaneous fracture. Three animals ( 2 males, 1 female) from group 4 (T4) showed clinical signs of HNS on face bones. Parathyroid hormone (PTH) mean concentrations are listed in Table 2. Treatments without oxalate (treatments 1 and 3) did not show significant changes over time, as expected. Treatments containing oxalate (treatments 2 and 4), there were significant reductions in approximately fifty per cent (Day 90, Treatment 2; Day 60, Treatment 4 ), with a gradual rise at the end of the test. A significant difference $(\mathrm{P}<0.05)$ was observed between values measured on Day 30 and Day 90 , but there were no differences between other time points. There was no time and treatment effects on calcitonin levels, and the average values are shown in Table 3.

Radiographic third metacarpal evaluation was correlated with body weight values. Mean values and standard errors of mean for bone mineral density (BMD) and weights of animals of the different treatments are described in Table 4. No significant effect was observed for treatment and time elapsed. Mean values and standard deviations of calcium and phosphate concentrations in bone $\left(\mathrm{gkg}^{-1}\right)$ according to the treatments are showed in Table 5. There was no significant effect of treatment or time.

Table 2. Mean and standard deviation of parathyroid hormone (PTH) $(\mathrm{pg} / \mathrm{mL})$ in different treatments $(\mathrm{T})$

\begin{tabular}{cccccc}
\hline & Day 30 & Day 60 & Day 90 & Day 120 & Day 150 \\
\hline T1 & $58.2^{\mathrm{bA}} \pm 50.0$ & $77.3^{\mathrm{aA}^{\mathrm{aA}}} \pm 80.9$ & $36.3^{\mathrm{bA}} \pm 38.7$ & $17.3^{\mathrm{aA}} \pm 21.8$ & $72.0^{\mathrm{aA}_{2}} \pm 88.8$ \\
$\mathrm{~T} 2$ & $81.5^{\mathrm{bAB}} \pm 29.8$ & $49.3^{\mathrm{aAB}} \pm 41.3$ & $26.6^{\mathrm{bB}} \pm 37.4$ & $49.5^{\mathrm{aAB}} \pm 84.7$ & $75.0^{\mathrm{aA}} \pm 97.0$ \\
$\mathrm{~T} 3$ & $190.6^{\mathrm{aAA}} \pm 196.6$ & $79.0^{\mathrm{aA}} \pm 82.5$ & $60.0^{\mathrm{bA}} \pm 48.3$ & $85.0^{\mathrm{aA}} \pm 153.4$ & $47.3^{\mathrm{aA}} \pm 45.6$ \\
$\mathrm{~T} 4$ & $981.1^{\mathrm{aA}} \pm 891.9$ & $60.0^{\mathrm{aC}} \pm 47.4$ & $490.3^{\mathrm{aAB}} \pm 551.9$ & $113.0^{\mathrm{aC}} \pm 161.6$ & $217.8^{\mathrm{aBC}} \pm 223.2$ \\
\hline
\end{tabular}

Means followed by different letters (uppercase and lowercase letters in columns in the rows) differ by Tukey test at a significance level of $0.05 . \mathrm{T} 1=$ chelated minerals, $\mathrm{T} 2=$ chelated minerals + oxalate, $\mathrm{T} 3=$ not chelated minerals, $\mathrm{T} 4=$ not chelated minerals + oxalate.

Table 3. Mean values and standard deviation for calcitonin $(\mathrm{pg} / \mathrm{mL})$ in different treatments $(\mathrm{T})$

\begin{tabular}{lccccc}
\hline & Day 30 & Day 60 & Day 90 & Day 120 & Day 150 \\
\hline T1 & $2.18 \pm 0.34$ & 2.00 & $2.08 \pm 0.20$ & $2.68 \pm 1.52$ & 2.00 \\
T2 & $2.67 \pm 1.40$ & 2.00 & $2.53 \pm 1.31$ & $2.16 \pm 0.26$ & $2.02 \pm 0.04$ \\
T3 & $2.04 \pm 0.09$ & $2.37 \pm 0.90$ & $2.22 \pm 0.53$ & $2.15 \pm 0.23$ & 2.00 \\
T4 & $2.15 \pm 0.23$ & $2.33 \pm 0.82$ & 2.00 & $2.12 \pm 0.18$ & 2.00 \\
\hline
\end{tabular}

$\mathrm{T} 1=$ chelated minerals, $\mathrm{T} 2=$ chelated minerals + oxalate, $\mathrm{T} 3=$ not chelated minerals, $\mathrm{T} 4=$ not chelated minerals + oxalate. 
Table 4. Mean and standard error of the mean (SEM), bone mineral density (BMD) in millimeters of aluminum $(\mathrm{mmAl})$ and animal weights $(\mathrm{kg})$ by treatment $(\mathrm{T})$

\begin{tabular}{lcccccccc}
\hline \multirow{2}{*}{ Periods } & \multicolumn{2}{c}{ T1 } & \multicolumn{2}{c}{ T2 } & \multicolumn{2}{c}{ T3 } & \multicolumn{2}{c}{ T 4 } \\
\cline { 2 - 8 } & BMD & Weight & BMD & Weight & BMD & Weight & BMD & Weight \\
\hline D-0 & 12.77 & 309.50 & 13.85 & 280.17 & 14.36 & 280.17 & 13.46 & 271.83 \\
D-30 & 14.47 & 337.00 & 15.61 & 304.00 & 15.98 & 320.33 & 16.28 & 306.67 \\
D-60 & 16.90 & 347.67 & 17.23 & 326.50 & 18.12 & 334.00 & 16.63 & 322.67 \\
D-90 & 18.12 & 355.67 & 17.95 & 324.33 & 17.73 & 341.17 & 18.19 & 329.50 \\
D-120 & 19.34 & 368.67 & 20.07 & 336.17 & 20.19 & 352.83 & 20.63 & 339.00 \\
D-150 & 18.57 & 379.17 & 18.66 & 344.00 & 18.94 & 356.00 & 18.47 & 348.17 \\
SEM & 2.57 & 24.68 & 2.22 & 23.40 & 2.09 & 27.97 & 2.43 & 27.38 \\
\hline
\end{tabular}

$\mathrm{T} 1=$ chelated minerals, $\mathrm{T} 2=$ chelated minerals + oxalate, $\mathrm{T} 3=$ not chelated minerals, $\mathrm{T} 4=$ not chelated minerals + oxalate.

Table 5. Means and standard errors of the mean (SEM) of calcium $(\mathrm{Ca})$ and phosphorus $(\mathrm{P})$ in bones $\left(\mathrm{gkg}^{-}\right.$ 1) by treatment $(\mathrm{T})$

\begin{tabular}{lcccccccc}
\hline \multirow{2}{*}{ Periods } & \multicolumn{2}{c}{ T1 } & \multicolumn{2}{c}{ T2 } & \multicolumn{2}{c}{ T3 } & \multicolumn{2}{c}{ T4 } \\
\cline { 2 - 9 } & $\mathrm{Ca}$ & $\mathrm{P}$ & $\mathrm{Ca}$ & $\mathrm{P}$ & $\mathrm{Ca}$ & $\mathrm{P}$ & $\mathrm{Ca}$ & $\mathrm{P}$ \\
\hline D-0 & 30.99 & 16.12 & 31.70 & 16.11 & 32.35 & 15.75 & 30.70 & 16.13 \\
D-75 & 30.91 & 15.84 & 31.05 & 14.94 & 30.91 & 15.45 & 30.71 & 14.71 \\
D-150 & 29.74 & 14.56 & 30.63 & 15.34 & 29.75 & 14.73 & 28.84 & 14.40 \\
SEM & 0.70 & 0.83 & 0.54 & 0.59 & 1.30 & 0.52 & 1.08 & 0.92 \\
\hline
\end{tabular}

$\mathrm{T} 1=$ chelated minerals, $\mathrm{T} 2=$ chelated minerals + oxalate, $\mathrm{T} 3=$ not chelated minerals, $\mathrm{T} 4=$ not chelated minerals + oxalate

\section{DISCUSSION}

In order to induce mineral imbalance, potassium oxalate concentrations ( $2.5 \%$ for each meal) were calculated based on related pasture levels. Clinical signs of NSH were observed only in Treatment 4. Kienzle and Zorn (2006) reported potassium oxalate present in pastures, with concentrations greater than $25 \mathrm{gkg}^{-1}$ of dry matter, causing reduction in $\mathrm{Ca}$ bioavailability. According to Miyasaki et al. (2003), this imbalance is a common problem in tropical plants that usually have high concentrations of potassium oxalate and low rate of $\mathrm{Ca}$.

According to the study proposed by Herrick (1993), there are some parameters for a mineral to be considered an essential mineral, including if its addition in the diet prevents or reverses an abnormality. In the present study, there were no clinical changes or signs of lameness in animals in the group challenged with potassium oxalate and supplemented with chelated minerals (Treatment 2).

Other important parameters in this classification involves the presence of this mineral in healthy tissues, its constant concentration between animals of the same species, and abnormalities of structure and function described when they are removed (Herrick, 1993).

In case of calcium, before structural and functional abnormalities, compensatory tissue mechanisms for maintaining homeostasis can be activated. The serum calcium level is tightly regulated by the secretion of Parathyroid Hormone (PTH) (Sandeep and Dipayan, 2017). PTH synthesis has a highly sensitive negative correlation to calcium (Fradinho et al., 2018), proving a greater chelated minerals availability; furthermore, calcium receptors in parathyroid cells can recognize other cations such as magnesium (Garret et al., 1995). In the present study, PTH mean values corroborate with data from Estepa et al. (2003), were PTH ranged from $4-65 \mathrm{pg} \mathrm{mL}^{-1}$ in healthy horses, and from 110 $518 \mathrm{pg} \mathrm{mL}^{-1}$ in animals with NSH. The most likely cause of the increased PTH values would be a very mild form of primary hyperparathyroidism or secondary hyperparathyroidism.

As primary hyperparathyroidism is rare in horses (Tomlinson et al., 2014), the model proposed in the present study effectively induced NSH. Differences in PTH values (pg $\left.\mathrm{mL}^{-1}\right)$ were observed between not chelated mineral + oxalate 
group (Treatment 4) and other treatments (Treatment 1, Treatment 2, Treatment 3).

PTH mean concentrations on treatment 4 was 5.75 times greater than the average of treatments 1,2 and 3 . The average rate in oxalate treated groups was $214.43 \mathrm{pg} / \mathrm{mL}$, but it should be noted that PTH mean concentrations was much lower in chelated minerals group $\left(54.32 \mathrm{pg} \mathrm{mL}^{-1}\right)$, when compared with not chelated minerals group $\left(232.43 \mathrm{pg} \mathrm{mL}^{-}\right.$ ${ }^{1}$ ). These data demonstrate the chelated minerals ability to prevent bone reabsorption and the subsequent development of fibrous osteodystrophy. No difference in calcitonin concentration was observed between treatments, corroborating with a Rourke et al. (2009) study. According to the authors, thyroid C cells rapidly respond to extracellular calcium concentration changes by secreting large amounts of calcitonin into circulation. They suggest that calcitonin is important for acute calcium homeostasis and is not a useful indicator of longterm imbalance.

According to Prado-Filho and Sterman (2004), the present study showed no difference between treatments or sex. When measuring minerals in the body, the highest concentration of minerals, and thus the most important organs to study, are found in the liver, blood, skeletal muscles, and bone (Georgievskii et al., 1979). Fradinho et al. (2018), reported substantial changes in bone quality and blood indicators during the first three years of horse's life. Furthermore, these changes are related to age, but are also affected by factors such as sex and time of birth. In foals, the calcium and phosphorus ratio imbalance are frequently observed (Capen, 1980).

According to Frape (2016), bone acts as a reservoir for both minerals and can be used if diets does not reach its nutritional requirements. Bone has a 2:1 calcium: phosphorus ratio, while the rest of the body has a 1.7:1 ratio due to the distribution of phosphorus in soft tissues (Frape, 2016). Bone mineral density (BMD), defined as the mineral concentration per bone volume, is a practical, inexpensive and non-invasive method for quantifying radiological changes (Nielsen et al., 1997; Reichmann et al., 2004). The minerals are incorporated into the organic matrix of the skeleton to increase hardness and rigidity and are also directly related to bone material properties and histological characteristics (McClure et al., 2001).

There was an expected high correlation $(\mathrm{P}<0.0001)$ between BMD and weight gain. In this study, BMD means $(20.1 \pm 0.5 \mathrm{mmAl})$ went beyond literature described levels for the third metacarpal (14.2 $\pm 2.2 \mathrm{mmAl})$ (Santos et al., 2008). BMD mean values were reduced at the end of the experimental period, as well as the decreased BMD values on long bone confirmed by histological method on Riet-Correa et al. (1998) study. Previous study has also reported a high correlation using quantitative ultrasound to assess BMD in the third metacarpal of horses (Santos et al., 2008).

Despite being a non-invasive method, BMD showed gaps that could be filled by other methods, like bone calcium, obtained from biopsy. In the present study, differences in bone calcium values were observed between the groups that received potassium oxalate. Bone calcium concentrations in chelated minerals + oxalate group (Treatment 2) was numerically higher than in not chelated minerals + oxalate group (Treatment 4). According to Gordon et al. (2013), this finding may indicate lower chelated mobilization in body fluids.

\section{CONCLUSIONS}

The use of chelated minerals in diets with potassium oxalate compounds improves the resistance to calcium and phosphorus imbalance by horses. Yearlings supplemented with chelated minerals show stability in serum parathyroid hormone levels and avoided mineral imbalances and fibrous osteodystrophy even when in dietary potassium oxalate challenged.

\section{ACKNOWLEDGEMENTS}

We would like to thank Tortuga Companhia Zootécnica Agrária for providing the material, and the Foundation for Research Support of São Paulo State (FAPESP) for funding the research project. 


\section{REFERENCES}

AMMERMAN, C.B.; BAKER D.H.; LEWIS A.J. Copper bioavailability. In: BAKER D.H.; AMMERMAN, C.B. (Eds.). Bioavailability of nutrients for animals: amino acids, minerals, and vitamins. San Diego: Academic Press, 1995. p.127-156.

BAKER, L.A.; WRIGLEY, M.R.; PIPKEN, J.L.; HALIBURTON, J.T.; BACHMAN, R.C. Digestibility and retention of inorganic and organic sources of copper and zinc in mature horses. In: EQUINE SCIENCE SYMPOSIUM, 19., 2005, Champaign. Proceedings... Champaign: [s.n.], 2005. p.162-165.

BARBER, P.J. Disorders of the parathyroid glands. J. Feline Med. Surg., v.6, p.259-269, 2004.

BLANEY, B.J.; GARTNER, R.J.W.; MCKENZIE; R.A. The inability of horses to absorb calcium oxalate. J. Agric. Sci., v.97, p.639$641,1981$.

BRASIL. Ministério da Agricultura, Pecuária e Abastecimento. Métodos Oficiais. SNADLANARD. 1988.

CAPEN, C.C. The calcium regulating hormones: parathyroid hormone, calcitonin and cholecalciferol. In: McDONALD, L.E. (Ed.). Veterinary endocrinology and reproduction. 3.ed. Philadelphia: Lea \& Febiger, 1980. p.60-130.

ESTEPA, J.C.; GARFIA, B.; GAO, P. et al. Validation and clinical utility of a novel immunoradiometric assay exclusively for biologically active whole parathyroid hormone in the horse. Equine Vet. J., v.35, p.291-295, 2003.

FAIRWEATHER-TAIT, S.; HURRELL, R.F. Bioavailability of minerals and trace elements. Nut. Res. Rev., v.9, p.295-324, 1996.

FORBES, R.M.; ERDMAN, J. Bioavailability of trace mineral elements. Ann. Rev. Nutr. v.3, p.213-231, 1983.

FRADINHO, M.J.; MATEUS, L.; BESSA, R.J.B. et al. Age-related changes of bone ultrasound measurements and metabolic indicators in the young horse. Livest. Sci., v.211, p.104-110, 2018.
FRAPE, D. Nutrição e alimentação de equinos. 3.ed. São Paulo: Roca, 2016. 602p.

GARRETT, J.E.; CAPUANO, I.V.; HAMMERLAND, L.G. et al. Molecular cloning and functional expression of human parathyroid calcium receptor cDNAs. J. Biol. Chem., v.270, p.12919-12925, 1995.

GEORGIEVSKII, V.I.; ANNENKOV, B.N.; SAMOKHIN, V.T. Mineral nutrition of animals. Moscow: Kolos Publishing House, 1979.

GORDON, M.E.; EDWARDS, M.S.; SWEENEY, C.R.; JERINA, M.L. Effects of added chelated trace minerals, organic selenium, yeast culture, diet-fed microbials, and Yucca schidigera extract in horses. Part II. Nutrient excretion and potential environmental impact. $J$. Anim. Sci., v.91, p.3909-3916, 2013.

HERBERT, E.W.; DITTMER, K.E. Acute and chronic oxalate toxicity in Miniature Horses associatedwith soursob (Oxalis pes-caprae) ingestion: case report. Equine Vet. Educ., v.29, p.549-557, 2017.

HERRICK, J.B. Minerals in animal health. In: ASHMEAD, H.D. The roles of amino acid chelates in animal nutrition. New Jersey: Noyes Publications, 1993. p.3-20.

KIENZLE, E.; ZORN, N. Bioavailability of minerals in the horse. In: EUROPEAN EQUINE NUTRITION AND HEALTH CONGRESS, 3., 2006, Merelbeke. Procedings... Merelbeke, Belgium: Ghent Unversity, 2006. p.17-18.

LESSON, S.; SUMMERS, J.D. Commercial poultry nutrition. 2.ed. Guelph, Ontario, Canada: University Books, 1997. 413p.

MCCLURE, R.S.; GLICKMAN, L.T.; GLICKMAN, N.W.; WEAVER, C.M. Evaluation of dual energy $\mathrm{x}$ ray absorptiometry for in situ measurement of bone mineral density of equine metacarpi. Am. J. Vet. Res., v.62, p.752-756, 2001.

MELLOR, D. Historical background and fundamental concepts "of chelation". In: DWYER, F.; MELLOR, D. Chelating agents and metal chelates. New York: Academic Press, 1964. $546 \mathrm{p}$. 
MILLER, E.D.; BAKE, L.A.; PIPKE, J.L. et al. The effect of supplemental inorganic and organic forms of copper and zinc on digestibility in yearling geldings in training. EQUINE SCIENCE SYMPOSIUM, 19., 2003, Champaign. Proceedings... Champaign: [s.n.], 2003. p.107112.

MIYAZAKI, S.; YAMANAKA, N.; GURUGE, K.S. Simple capillary electrophoretic determination of soluble oxalate and nitrate in forage grasses. J. Vet. Diag. Invest., v.15, p.480483, 2003.

NIELSEN, B.D.; POTTER, G.D.; MORRIS, E.L. et al. Changes in the third metacarpal bone and frequency of bone injuries in young quarter horses during race training - observations and theoretical considerations. J. Equine Vet. Sci., v.17, p.541549, 1997.

NUNES, S.G.; SILVA, J.M.; SCHENK, J.A. Avaliação de gramíneas forrageiras para equinos. Campo Grande, MS: Embrapa-CNPGC, 1990. (Comunicado Técnico, 31).

NUTRIENT requirements of horses. 6.ed. Washington: Nutrient Requirements Council, National Academy of Science, 2007.

OSPINA, J.C.; DONCEL, B.; GARCÍA, N.V. Maxillofacial fibrous osteodystrophy in equine: case report. Braz. J. Vet. Pathol., v.2, p.100-105, 2014.

OTT, E.A.; ASQUITH, R.L. Trace mineral supplementation of broodmares. J. Equine Vet. Sci., v.14, p.93-101, 1994.

OTT, E.A.; JOHNSON, E.L. Effect of trace mineral on growth and skeletal and hoof development in yearling horses. J. Equine Vet. Sci., v.21, p.287-292, 2001.

PRADO-FILHO, J.R.C.; STERMAN, F.A. Evaluation of mineral bone density in thoroughbred horses under an initial training programme. Braz. J. Vet. Res. Anim. Sci., v.41, p.384-388, 2004.

PUOLI FILHO, J.N.P.; COSTA, C.; ARRIGONI, M.B. et al. Suplementação mineral e mobilização de cálcio nos ossos de equinos em pastagem de Brachiaria humidicola. Pesqui. Agropecu. Bras. v.34, p.873-878, 1999.
REICHMANN, P.; MOURE, A.; GAMBA, H.R. Bone mineral content of the third metacarpal bone in quarter horse foals from birth to one year of age. J. Equine Vet. Sci., v.24, p.391-396, 2004.

RIET-CORREA, F.; SOARES, M.P.; MENDEZ, M.C. Intoxicações em equinos no Brasil. Ciênc. Rural, v.28, p.715-722, 1998.

ROURKE, K.M.; KOHN, C.W.; LEVINE, A.L. et al. Rapid calcitonin response to experimental hypercalcemia in healthy horses. Domest. Anim. Endocrinol., v.36, p.197-201, 2009.

SANDEEP, D.; DIPAYAN, C. Role of low calcium and high calcium diet on adipocyte metabolism with respect to serum Parathyroid Hormone (PTH) levels in male wistar rats. Indian J. Physiol. Pharmacol., v.61, p.430-439, 2017.

SANTOS, T.C.C.; VULCANO, L.C.; MACHADO, V.M.V. Determinação de densidade mineral óssea do terceiro metacarpiano de equinos por meio da densitometria óptica radiográfica e sua correlação com a ultrassonografia quantitativa. Vet. Zootec., v.15, p.267-277, 2008.

SICILIANO, P.D.; CULLEY, K.D.; ENGLE, T.E. Effect of trace mineral source (inorganic vs. organic) on trace mineral status in horses. In: EQUINE NUTRITION PHYSIOLOGY SYMPOSIUM, 17., 2001, Lexington. Proceedings... Lexington, KY, p.419-420, 2001.

SILVA, J.H.V.; PASCOAL, L.A.F. Função e disponibilidade dos minerais. In: SAKOMURA, N.K.; SILVA, J.H.V.; COSTA, F.G.P.; FERNANDES, J.B.K.; HAULSCHILD, L. Nutrição de não ruminantes. Jaboticabal, SP: FUNEP, 2014. p128-142.

SPEARS, J.W. Organic trace minerals in ruminant nutrition. Anim. Feed Sci. Technol., v.58, p.151-163, 1996. 
STANEK, M.; JAWORSKI, Z.; SOBOTKA, W. et al. Influence of an organic supplement of copper, zinc and manganese in feed rations on concentrations of these elements in the coat of Polish Konik horses. J. Element., v.21, p.549-558, 2016.

SWARTZMANN, J.A.; HINTZ, H.F.; SCHRYVER, H.F. Inhibition of calcium absorption in ponies fed diets containing oxalic acid. Am. J. Vet. Res., v.3, p.1621-1623, 1978.

TOMLINSON, J.E.; JOHNSON, A.L.; ROSS, M.W. et al. Successful detection and removal of a functional parathyroid adenoma in a pony using technetium Tc $99 \mathrm{~m}$ sestamibi scintigraphy. J. Vet. Int. Med., v.28, p.687-692, 2014.
VULCANO, L.C.; MENDES, R.G.; GODOY, C.L.B. et al. Padronização da densidade mineral óssea (DMO) do acessório do carpo em equinos atletas da raça Quarto de Milha. Ciênc. Rural, v.36, p.520-524, 2006.

WAGNER, E.L.; POTTER, G.D.; ELLER, E.M. et al. Absorption and retention of trace minerals in adult horses. Prof. Anim. Sci., v.21, p.207-211, 2005.

YENICE, E.C.; MIZRAK, M.; GULTEKIN, Z. et al. Effects of organic and inorganic forms of manganese, zinc, copper, and chromium on bioavailability of these minerals and calcium in late-phase laying hens. Biol. Trace Elemen. Res., v.167, p.300-307, 2015. 